\title{
直噴ガソリン機関用燃料噴霧の二方向速度同時評価*
}

\author{
小林 義幸 ${ }^{* 1}$, 石間 経章*1, 小保方 富夫 ${ }^{* 2}$, 森田 照義*3, 山田 卓也 ${ }^{* 4}$
}

\section{Evaluation of Two - Dimensional Velocities of Fuel Sprays for Gasoline Direct Injection Engines}

\author{
Yoshiyuki KOBAYASHI ${ }^{* 1}$, Tsuneaki ISHIMA, Tomio OBOKATA, \\ Teruyoshi MORITA and Takuya YAMADA \\ ${ }^{* 1}$ Gunma Univ. Dept. of Mechanical System Engineering \\ Tenjin 1-5-1, Kiryu-shi, Gunma, 376-8515 Japan
}

An experimental study on fuel sprays for direct injection gasoline engines was carried out in order to evaluate spray velocity characteristics. Tested injectors were swirl and outwardly opening type ones, and formed sprays into a pressure chamber in which the pressure was set to $0.1 \mathrm{MPa}$ and 1.1 MPa. The spray velocity was measured by two components laser Doppler anemometry and was processed by a time-dividing method which divided the phase-matched spray information into five distinct time periods. By the increase in back pressure, the spray development was limited in axial direction for the swirl type injector, while spray developing direction was not changed for the outwardly opening type injector. Under high back pressure condition, the axial velocity fluctuation for the swirl type injector was larger than that of radial component, while the axial velocity fluctuation for the outwardly opening type injector was comparable with that of radial component. Strong correlation of axial and radial velocity fluctuations was observed except for the condition of the swirl type injector with high back pressure.

Key Words : Fuel Injection, Atomization, Gasoline Engine, Direct Injection, Laser Doppler Velocimeter

\section{1. 緒言}

ガソリン直噴機関の性能改善のため, 高圧ガソリン噴霧性状の理解が必要とされている.そのような背景から, 加圧雾囲気下での噴霧形状に関する研究 ${ }^{(1)}$, 噴射率と噴霧特性の相互評価 ${ }^{(2)}$, 時間分割法を用いた評価 ${ }^{(2)}$, 噴霧 とその周囲流の同時計測 ${ }^{(3)}$ ，ノズル近傍の噴霧速度および液滴径計測 ${ }^{(4)}$, 高温高圧下における噴霧特性評価 ${ }^{(5)}$ など多くの研究が行われている.

しかしながら，従来の高圧ガソリン噴霧の研究において噴霧速度は平均值で評価されることが多く，その変動 速度については，報告された例がほとんどない，一方，ディーゼル噴霧の変動速度は過去に報告されており，噴 霧の拡散を表すうえで重要なデータとして扱われている(6) - (9). したがって，高圧ガソリン噴霧の速度情報に対し ても同様の統計処理を行い，ディーゼル噴霧とデータを共有することは噴霧構造理解のために重要となる.

本研究では，直噴ガソリン機関の均質燃焼および成層燃焼時の筒内圧に対応する大気圧および加圧雰囲気条件 のもとで，直噴ガソリン機関用噴射弁による噴霧の速度特性を評価することを目的とする．噴射弁としてスワー

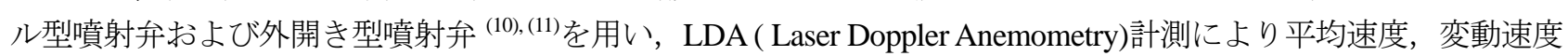
および二方向速度相関を求めた。 これらをレーザシートによる噴霧の可視化結果 ${ }^{(5)}$ とわおせて報告する.

* 原稿受付 2011 年 9 月 24 日 改訂原稿受付日 2012 年 6 月 27 日

*1 正員, 群馬大学大学院工学研究科 (下376-8515 群馬県桐生市天神町 1-5-1)

*2 正員, フェロー, 群馬大学名誉教授（广376-8515 群馬県桐生市天神町 1-5-1）

*3 (株) 本田技術研究所（广321-3393 杤木県芳賀郡芳賀町下高根沢 4630 番地）

*4 正員, (株) 本田技術研究所

E-mail: ishima@gunma-u.ac.jp 


\section{2. 実験装置および方法}

本研究の可視化実験配置を図 1 に示す. 燃料は高圧ポンプにより絶対圧 $10.1 \mathrm{MPa}$ に加圧され, 圧力容器に取り 付けられた噴射弁に供給される。噴射期間および噴射周波数はインジェクションタイミングコントローラによっ て制御される. 圧力容器観測空の曇り止めのため, 計測中はつねに容器内に窒素ガスを流した. 窒素ガスの流速 は容器内で最大 $0.04 \mathrm{~m} / \mathrm{s}$ であり噴霧への影響は無視できる．容器内圧力は背圧弁により調整した．なお，実験は 背圧 0.1MPa および 1.1MPa (ともに絶対圧)の 2 条件で行った. 燃料には実験の再現性, 安全性, 統一性を考慮し, ガソリンの代替としてノルマルヘプタンを用いた。ノルマルヘプタンの物性值をガソリンとともに表 1 に示寸. 図 1 では, 可視化光源としてアルゴンイオンレーザ ( Spectra Physics 2017, 総合出力 5.5 W) を用い, レンズ群に より厚さ約 $0.2 \mathrm{~mm}$ のシート光とした．撮影には高速度ビデオカメラ(Photron FASTCAM-APX)を用いた．フレー ムレート，シャッター速度はそれぞれ $10,000 \mathrm{fps}, 17 \mu \mathrm{s}$ とした．画像サイズは噴射弁による噴霧形状の違いを考 慮し，スワール型噴射弁の場合 $384 \times 544$ pixel，外開き型噴射弁の場合 $512 \times 512$ pixel とした。いずれの場合も空

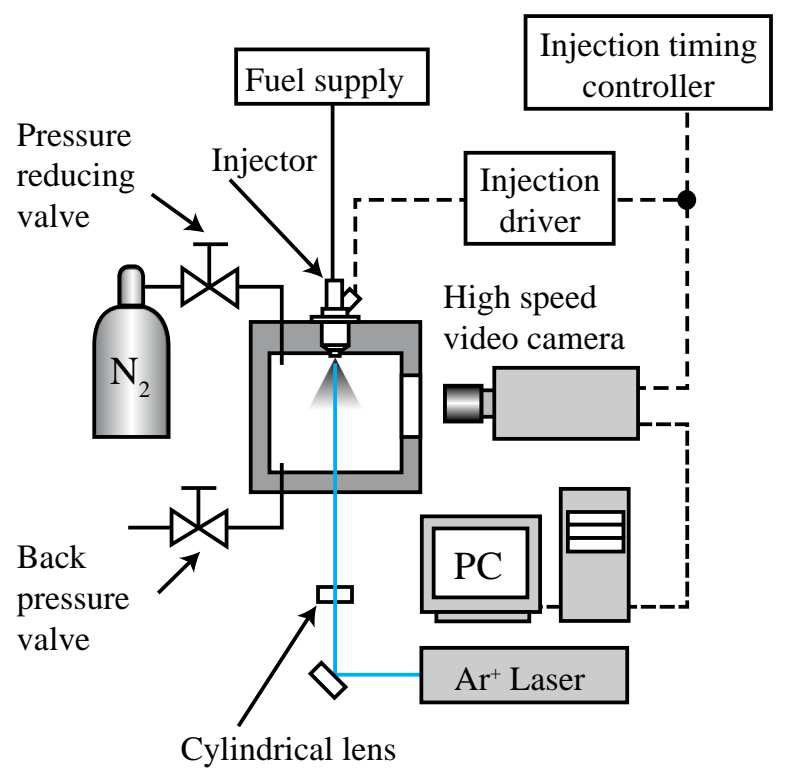

Fig. 1 Schematic diagram of the experimental setup for visualization of the spray.

Table 1 Physical properties of n-heptane and gasoline.

\begin{tabular}{l|c|c}
\hline & n-Heptane & Gasoline \\
\hline Density $\mathrm{kg} / \mathrm{m}^{3}$ & 684 & 745 \\
Kinematic viscosity $\mathrm{m}^{2} / \mathrm{s}$ & $0.61 \times 10^{-6}$ & $0.54 \times 10^{-6}$ \\
Refractive index & 1.385 & 1.410 \\
Surface tension $\mathrm{N} / \mathrm{m}$ & $20.9 \times 10^{-3}$ & $22.5 \times 10^{-3}$ \\
Volume expansion rate $\mathrm{K}^{-1}$ & $1.22 \times 10^{-3}$ & $0.83 \times 10^{-3}$ \\
\hline
\end{tabular}

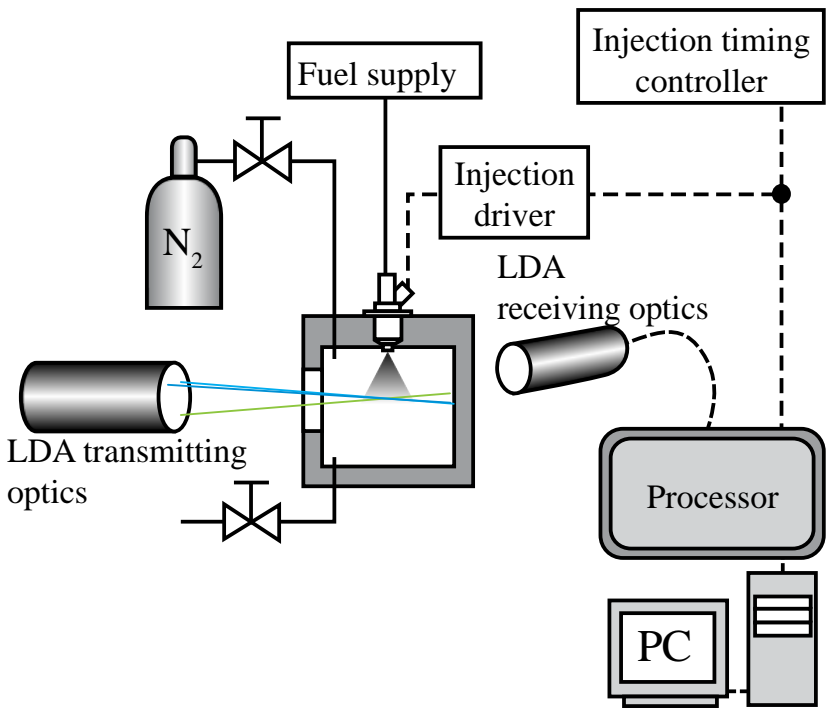

Fig. 2 Schematic diagram of the experimental setup for LDA measurements of the spray.

Table 2 Specification of the 2D LDA.

\begin{tabular}{l|r|r}
\hline Measurement direction & \multicolumn{1}{|c}{ Axial } & \multicolumn{1}{c}{ Radial } \\
\hline Wavelength $\mathrm{nm}$ & 515 & 488 \\
\hline Beam power mW & 30 & 20 \\
\hline Intersection angle deg. & 1.84 & 1.84 \\
\hline $\begin{array}{l}\text { Approxmate size of } \\
\text { measurement volume mm }\end{array}$ & $\phi 0.1 \times 3$ & $\phi 0.1 \times 3$ \\
\hline $\begin{array}{l}\text { Off - axis angle of receiving } \\
\text { optics deg. }\end{array}$ & 30 & 30 \\
\hline Fringe space $\mu \mathrm{m}$ & 7.8 & 7.5 \\
\hline Velocity range $\mathrm{m} / \mathrm{s}$ & $-58 \sim$ & $-56 \sim 168$ \\
\hline
\end{tabular}




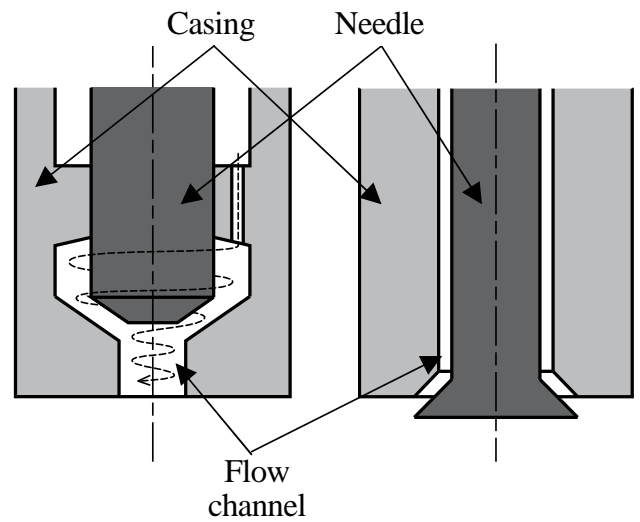

(a) Swirl type injector (b) Outwardly openning type injector

Fig. 3 Internal structure of the injectors

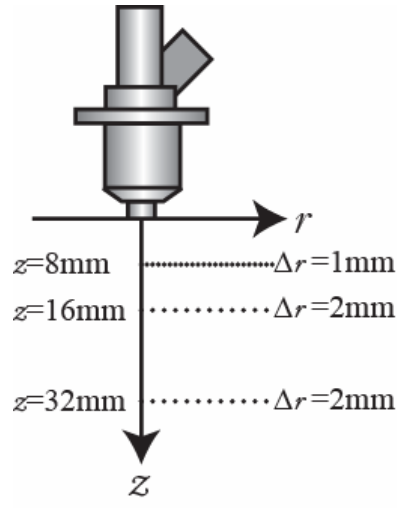

(a) Swirl type injector

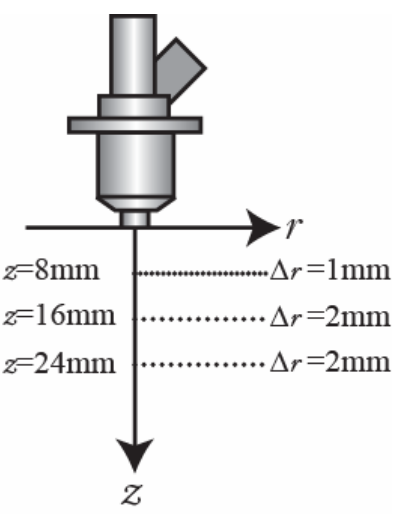

(b) Outwardly openning type injector

Fig. 4 Coordinate system and measurement positions.

間解像度は $0.073 \mathrm{~mm} /$ pixel とした。

噴霧の速度計測にはアルゴンイオンレーザからの 2 つの波長の光により二方向の速度成分を同時計測できる 2 次元 LDA（2DLDA）を用いた．装置概略を図 2 に，諸元を表 2 に示寸．信号処理器には，二次元用バーストス ペクトラムアナライザ（BSA，Dantec Dynamics F60）を用いた.

本研究ではスワール型および外開き型の 2 種類の噴射弁(試作品)を用いた。 スワール型噴射弁では噴射前の燃 料に周方向速度を与え，その遠心力により中空噴霧を形成する．外開き型噴射弁は針弁上面の円錐面に沿って燃 料が噴射されることにより中空噴霧を形成する．参考のため, 図 3 に両者の噴射弁構造の概略図を示す ${ }^{(12)}$. 本研 究では 2 種類の噴射弁の噴射期間を $0.7 \mathrm{~ms}$ で統一した. その際の噴射量はスワール型および外開き型噴射弁でそ

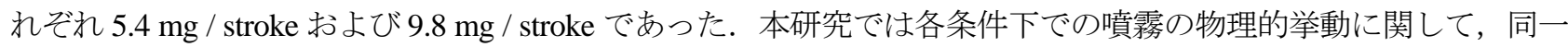
時刻における直観的な比較が容易となるよう，噴射期間を同一とし噴射量は一致させていない，なお，後述する 時間分割法を用いれば噴射期間によらない噴霧性状の評価が可能であり，噴射期間が変更された場合にも本研究 の手法は適用可能であると考えられる.

座標系と LDA 計測点を図 4 に示す. 座標系の原点は噴孔出口中央とした. 原点から噴射方向を $\mathrm{z}$ 軸, 噴霧半径 方向を $r$ 軸とした. 計測は $z=8,16,32 \mathrm{~mm}$ (スワール型噴射弁) $, z=8,16,24 \mathrm{~mm}$ (外開き型噴射弁)の半径線上 の各点で行った.

\section{3. 結果および考察}

\section{$3 \cdot 1$ 噴霧のベクトルマップ}

図 5 (a) - (c)にスワール型噴射弁の背圧0.1 MPaでのベクトルマップを噴霧中心断面の可視化結果とともに示寸. 噴霧速度ベクトルはウィンドウ平均(ウィンドウ幅 $0.2 \mathrm{~ms}$ )によって求めた. スワール型噴射弁からの噴霧は, 多 くの場合, 開弁直後に噴霧角が小さく速度の大きい先立ち噴霧が形成され，その後噴霧角が大きな主噴霧が形成 され(5)，本研究でも同様に定義する．図 5 (a)では，噴霧先端部分 $(z=16 \mathrm{~mm})$ に先立ち噴霧, $z=8 \mathrm{~mm}$ に主噴霧に よる速度ベクトルがそれぞれ観察される. 図 5 (b)および(c)のベクトルマップにおいて $\mathrm{z}=8 \mathrm{~mm}$ および $16 \mathrm{~mm} の$ 噴霧外側で噴霧内側方向へ向から流れが観察される，可視化結果とあわせて考えると，これらは噴霧外縁で形成 される大規模渦の発達によるものと思われる，なお，図 5(b)の画像では中心軸付近に噴霧画像があるものの， ス ワール噴霧の主噴霧(5)は中空形状でありこの領域では十分なデータ取得ができなかったため, 図ではベクトル表 示をしていない.一方で, 図 5(a)ではスワール弁の特徵である先立ち噴霧の存在 ${ }^{(2),(5)}$ のため, 図 5(c)では噴射終了 後の噴霧形状が閉じたときの液滴速度を計測しているために，中心軸上にもべクトルが存在する.

図 5 (d) - (f)にスワール型噴射弁の背圧 $1.1 \mathrm{MPa}$ での結果を示す. 図 5 (d)および(e)のベクトルマップでは, 背圧 $0.1 \mathrm{MPa}$ と異なり，上記のように定義した先立ち噴霧と主噴霧の区別が明確でない. 図 5 (e) の $z=8 \mathrm{~mm},|r|<10$ $\mathrm{mm}$ の領域, および 図 5(f) の $z=8,16 \mathrm{~mm},|r|<10 \mathrm{~mm}$ の領域において多くの速度ベクトルは軸方向を向いてお 


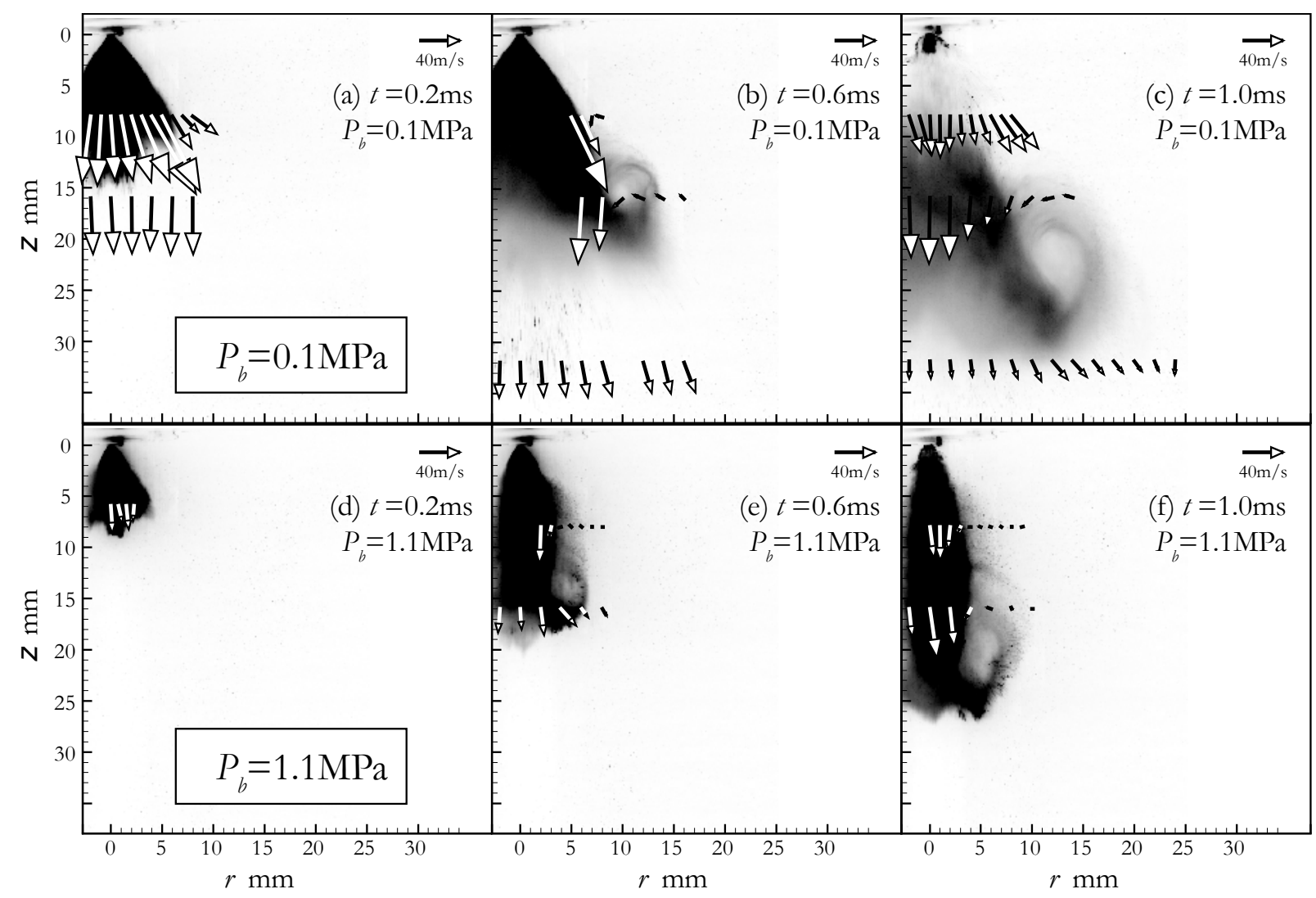

Fig. 5 Vector map of the spray velocity for the swirl type injector ( $P_{b}$ : back pressure, $t$ : time after start of injection).

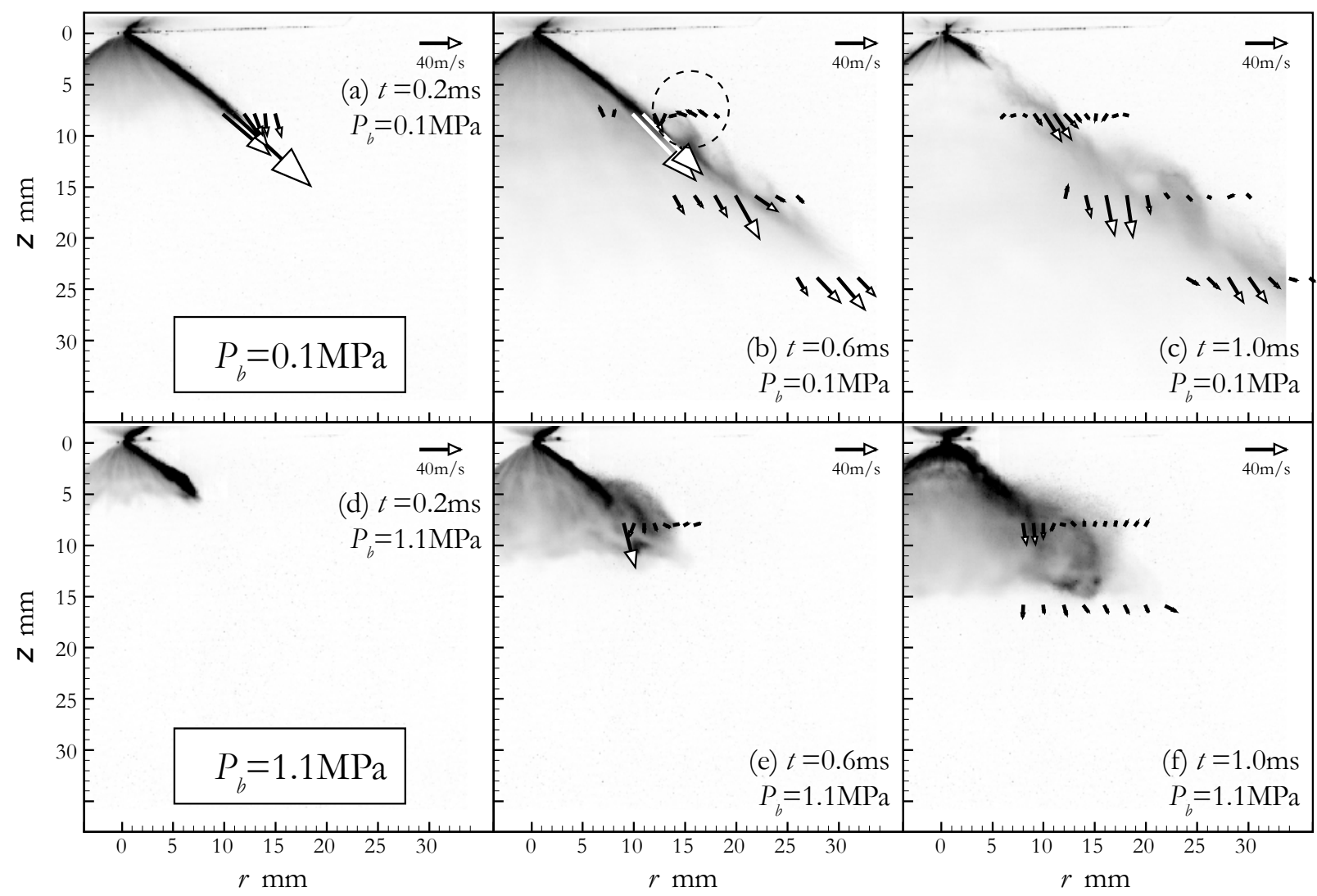

Fig. 6 Vector map of the spray velocity for the outwardly opening type injector ( $P_{b}$ : back pressure, $t$ : time after start of injection). 
り，噴霧外側向きの速度ベクトルはほとんどみられない。このように背圧 $1.1 \mathrm{MPa}$ では背圧 $0.1 \mathrm{MPa}$ とくらべて, 噴霧の軸方向に対して半径方向の発達が極端に小さくなる．また，全体的にみて背圧 $0.1 \mathrm{MPa}$ よりも噴霧速度べ クトルの絶対值が小さい. 液滴速度が小さくなる現象は, 背圧の増加にともない周囲空気の密度が大きくなり, 液滴に作用する抗力が増加するためである.

図 6 (a) - (c)に外開き型噴射弁の背圧 0.1 MPa での結果を示寸. 図 6 (a)のベクトルマップでは傘状に発達する噴 霧が観察される. 噴射弁の構造上, 図 5 (a)のスワール噴射弁の場合にみられた先立ち噴霧は形成されない. また, 噴霧は中空であり，中央部で液滴による速度ベクトルは現れない．図 6 (b)のベクトルマップの点線で囲んだ領域 において噴射口方向へ向かう噴霧速度が観察されている.これはディーゼル噴霧で観察される枝状構造 ${ }^{(13)}$ と同じ ものと考えられ，スワール型噴射弁の主噴霧先端に形成される渦も本質的に同様な原理で形成されるものと考え られる. 図6(c)のベクトルマップにおいて $z=16 \mathrm{~mm}, 12 \mathrm{~mm}<r<20 \mathrm{~mm}$ の領域でベクトルの向きが噴霧の発達 方向と一致しない，撮影時間 $t=1.0 \mathrm{~ms}$ では噴射は完了しており，噴霧液滴の数密度が減少しているため, 噴霧 は周囲空気の影響を受けやすくなる，よって，上述の現象は周囲空気の巻き込みにより，噴霧速度が局所的に変 化したものと考えられる. 図 6 (d) - (f)に外開き型噴射弁の背圧 $1.1 \mathrm{MPa}$ での結果を示す. 図 6 (d) - (f)のベクトル マップにおいて, スワール型噴射弁の場合とは異なり, 背圧が増加しても噴霧の発達方向は大きく変化しないこ とがわかる. 図 6 (d) - (f)のベクトルマップと, それに対応する背圧 $0.1 \mathrm{MPa}$ の結果と比較すると, 背圧 $1.1 \mathrm{MPa}$ では全体的に噴霧速度が小さい。

\section{$3 \cdot 2$ 噴霧速度の時間分割法およびデータ整理法}

図 7 (a)および(b)に噴射周期で重㸚合わせた時系列の軸方向液滴速度データの一例を示寸. これらはスワール型 噴射弁での背圧 0.1MPa の条件における $z=8 \mathrm{~mm}$ の(a) $r=0 \mathrm{~mm}$ および(b) $r=5 \mathrm{~mm}$ の位置での結果である. 図 7 (a) に示した $r=0 \mathrm{~mm}$ において, $0.2 \mathrm{~ms}$ と $1.2 \mathrm{~ms}$ 付近で 2 回液滴群が通過している. 最初の液滴群は先立ち噴霧, 次
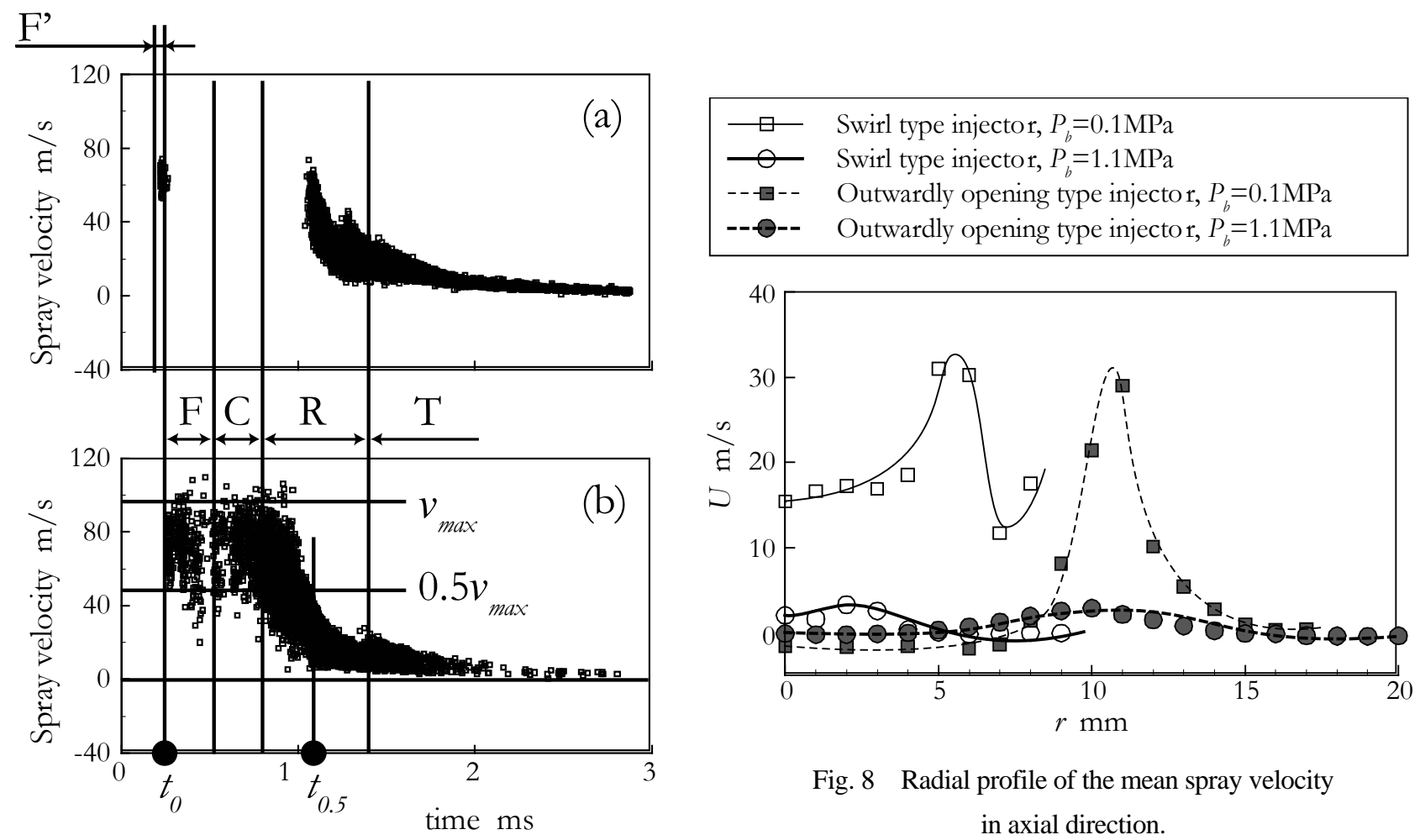

Fig. 8 Radial profile of the mean spray velocity in axial direction.

Fig. 7 Explanation of the time - dividing method

(Swirl type injector, $P_{b}=0.1 \mathrm{MPa}, z=8 \mathrm{~mm}$,

(a) $r=0 \mathrm{~mm}$, (b) $r=5 \mathrm{~mm}$ ). 
の液滴群は主噴霧に相当するものである(5). 図 7 (b)では, $0.3 \mathrm{~ms}$ で比較的高速の液滴群が到達する. 液滴群の速 度は $0.8 \mathrm{~ms}$ までほぼ同程度の速度域に分布し, その後, 徐々に減少しゼロに漸近する. 図 7 (b)では図 7 (a) とは異 なり F部で液滴は計測されていない，高速度ビデオによる可視化結果と合わせて考えると，F部は先立ち噴霧で あり，その後噴射角が大きく中空の主噴霧が形成されるとともに噴霧軸上で噴霧液滴は計測されず図 7 (a)のよう になり，噴霧外縁部では主噴霧の液滴を計測して図 7 (b)のような結果となる.

このような噴霧の時間的な変化を考慮して評価するために以降では時間分割法を用いる(2), (5). 時間分割法は噴 霧の速度情報を指標として噴霧を時間的な 5 つの区間(図 7)に分けてそれぞれを評価する. 時間分割法の実行手順 は以下のとおりである. まず図 8 のごとく軸方向平均噴霧速度の半径方向分布のグラフを求める. なお, ここで の平均噴霧速度には噴霧の非定常性を無視し, 単純に個数平均した值を用いる. 図 8 の各条件において, 平均噴 霧速度が最大となる $r$ 位置を求め, その位置において, 液滴が到達する時刻 $t_{0}$ と最大液滴速度 $v_{\text {max }}$ を図 7 (b)のよ うに求める.この際, 図 7(b)のように, 噴霧液滴群中で著しく大きい速度の液滴データは除外し, $v_{\max }$ を求めて いる. 次に $0.5 v_{\text {max }}$ より大きい液滴速度が存在しなくなる時刻を $t_{0.5}$ と定義する. $t_{0}$ と $t_{0.5}$ の間を図 7 (b)のように 3 等分し，前から F ( Front ), C ( Center ) 部と定義する．その次の区間は C 部の 2 倍の区間を R ( Rear ) 部と定義し, 残りを $\mathrm{T}$ ( Tail ) 部と定義する. 非定常噴霧は開弁に伴う先端の発達寸る領域，十分に開弁していて定常に近い状 態での噴霧，噴射弁が閉じる過程の噴霧，および噴射弁が完全に閉じている状態と大まかに分けることができる と考えられる. そこでこれらに対応するよう, F, C, R, T 部を噴霧の先端部分, 準定常部分, 減衰部分, 後流 部分として取り扱うこととする. 図7 (a)に図7 (b)で得られた各時間区間を $r=0 \mathrm{~mm}$ に対して適用した結果を示寸. ここでは先立ち噴霧があり， F 部以前に液滴が計測されるので, この区間を $\mathrm{F}^{\prime}$ 部と定義する. 各 $\mathrm{z}$ 位置のすべて の $r$ 位置の計測結果では同じ時間区間を適用する. 定義より, F, C, R, T の時間区間は噴射弁, 背圧条件，お よび $\mathrm{z}$ 位置によって異なる．以上の説明はスワール型噴射弁の場合であるが，外開き型噴射弁の場合も先立ち噴 霧 $\left(\mathrm{F}^{\prime}\right)$ がないことを除いては同様である. 以降の解析では噴霧の発達に重要であると考えられる F 部およびC 部 の噴霧挙動について平均噴霧速度, 变動速度, 二方向速度相関により評価した. これらの定義式を次に示す：

- 平均噴霧速度 (軸方向成分 $U$, 半径方向成分 $V$ )

$$
\begin{aligned}
& U=\frac{1}{n} \sum u \\
& V=\frac{1}{n} \sum v
\end{aligned}
$$

- 変動速度 (軸方向成分 $u_{r m s}^{\prime}$, 半径方向成分 $v_{r m s}^{\prime}$ )

$$
\begin{aligned}
& u_{r m s}^{\prime}=\sqrt{\frac{1}{n} \sum(u-U)^{2}} \\
& v_{r m s}^{\prime}=\sqrt{\frac{1}{n} \sum(v-V)^{2}}
\end{aligned}
$$

- 二方向速度相関 $\overline{u^{\prime} v^{\prime}}$

$$
\overline{u^{\prime} v^{\prime}}=\frac{1}{n} \sum(u-U)(v-V)
$$

Table $3 U_{\max }$ and $r_{U \max }$ under different conditions at $z=8 \mathrm{~mm}$.

\begin{tabular}{c|c|c|c}
\hline Injector type & $\begin{array}{c}\text { Back } \\
\text { pressure }\end{array}$ & $U_{\max } \mathrm{m} / \mathrm{s}$ & $r_{U \max } \quad \mathrm{mm}$ \\
\hline \multirow{2}{*}{$\begin{array}{c}\text { Swirl type } \\
\text { injector }\end{array}$} & $0.1 \mathrm{MPa}$ & 78 & 5 \\
\cline { 2 - 4 } & $1.1 \mathrm{MPa}$ & 36 & 2 \\
\hline $\begin{array}{c}\text { Outwardly } \\
\text { opening type } \\
\text { injector }\end{array}$ & $0.1 \mathrm{MPa}$ & 96 & 11 \\
\cline { 2 - 4 } & $1.1 \mathrm{MPa}$ & 48 & 9 \\
\hline
\end{tabular}


ここで $u$ おび $v$ は個々の噴霧液滴の軸方向および半径方向速度， $n$ は区間内のデータ点数を表す.

次節以降では, 以上の 3 種類の統計量の $z=8 \mathrm{~mm}$ における半径方向分布を示寸. その際, 各条件で $z=8 \mathrm{~mm} の$ C 部における最大值 $U_{\text {max }}$ を求め, これを用いて無次元化を行った. 参考のため, 各条件での $U_{\max }$ の值とそれが得 られた半径方向位置 $r_{U \max }$ を表 3 に示した。 ここで, 評価を行う $z$ 方向位置は, 図 5(b), 図 5(e), 図 6(b)および図 $6(\mathrm{e})$ から，噴射期間中に噴霧外側部分に巻き込夕等の特徵的な構造が観察された $z=8 \mathrm{~mm}$ とした. 従来研究では ノズル口径や雾囲気密度を用いて, $z$ 座標を無次元化して評価を行っている. しかしながら, 本研究で用いたよ うな半径方向に大きな広がりを持つ噴霧に対して，無次元化に適当なパラメータは現時点で明らかでない. よっ て本研究では $\mathrm{z}$ 座標の無次元化は行わず，直観的に理解しやすい実座標にて各条件での噴霧の評価を行った。 な お, 本研究では多数の噴射サイクルからなるアンサンブル平均処理から平均速度と変動速度を算出しており, 瞬 時の乱れとサイクル変動 ${ }^{(14)}$ との区別は行っていない.
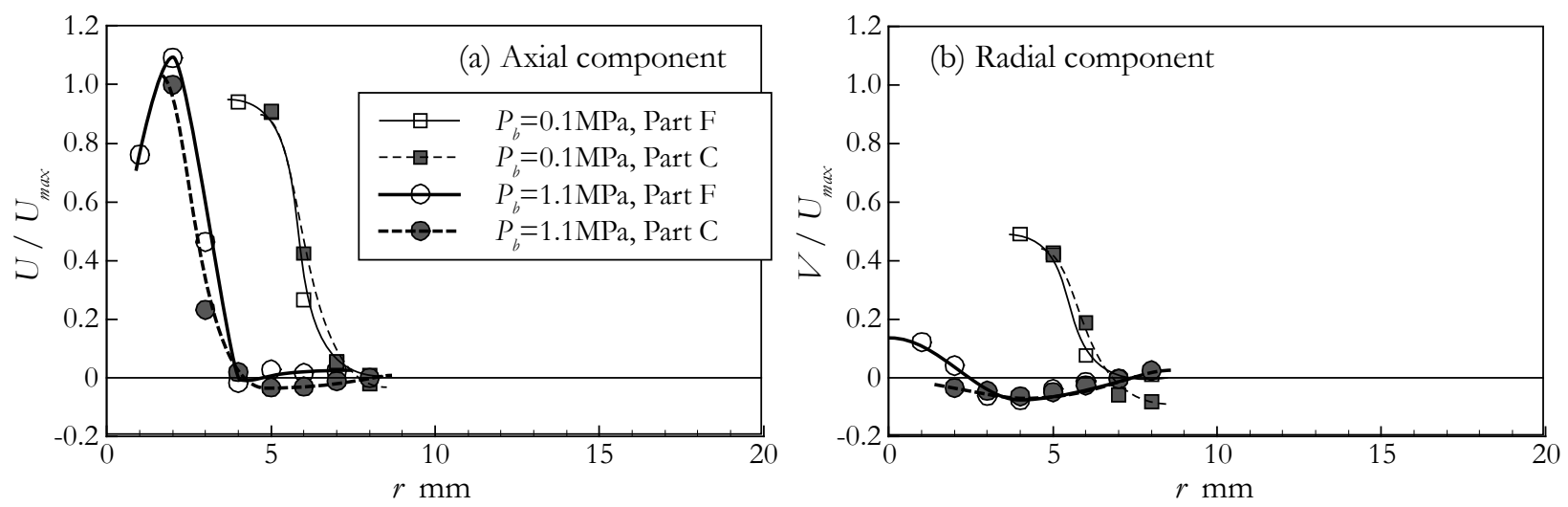

Fig. 9 Radial profile of the mean spray velocity for the swirl type injector at $z=8 \mathrm{~mm}$.
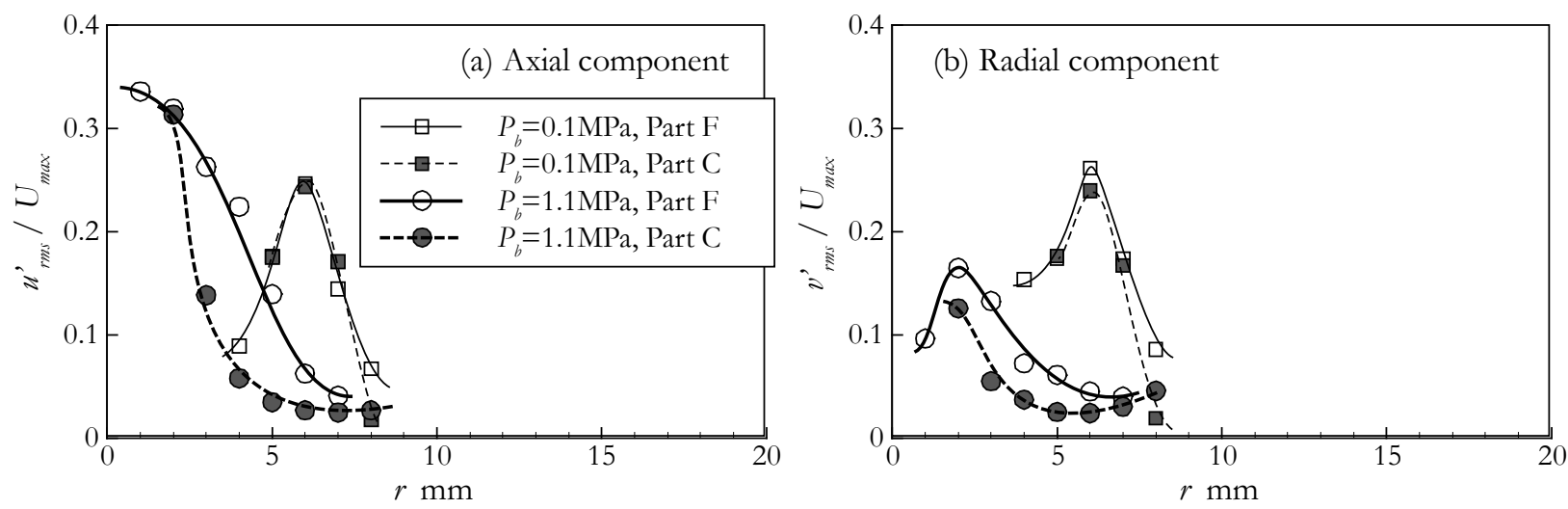

Fig. 10 Radial profile of the velocity fluctuation for the swirl type injector at $z=8 \mathrm{~mm}$.

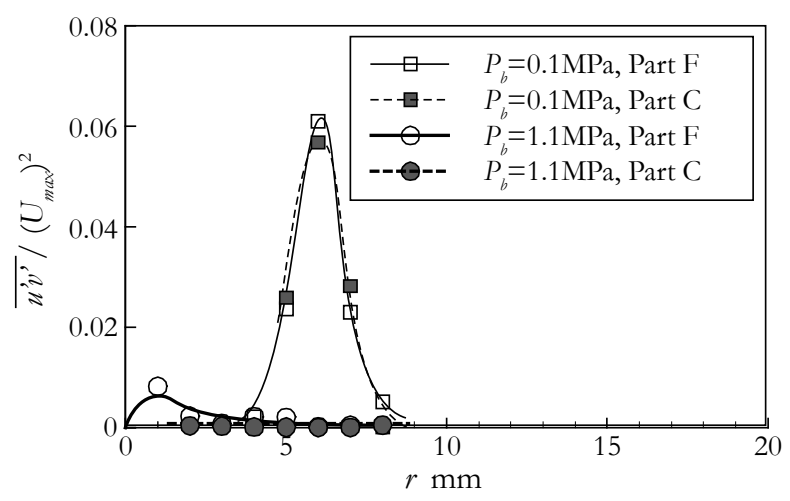

Fig. 11 Correlation of the velocity fluctuation in axial and radial directions for the swirl type injector at $z=8 \mathrm{~mm}$. 


\section{$3 \cdot 3$ 時間分割法を用いたスワール型噴射弁の噴霧速度評価}

図 9 にスワール型噴射弁の軸方向平均噴霧速度 $U$ および半径方向平均噴霧速度 $V$ を示す. 図 9 (a)において背圧 $0.1 \mathrm{MPa}$ では, F 部および C 部とも噴霧外縁に向かい急激に平均速度が減少しており, $r=6 \mathrm{~mm}$ 付近に速度勾配 の大きい領域が存在している. 背圧 $1.1 \mathrm{MPa} て ゙ は \mathrm{~F}$ 部, C 部ともに $r=3 \mathrm{~mm}$ 付近に大きい速度勾配が観察され, $r$ $>4 \mathrm{~mm}$ で速度分布は $0 \mathrm{~m} / \mathrm{s}$ 付近でほぼ一定となり，噴霧液滴が浮遊しているような状態となる．いずれの背圧で も F 部と C 部で大きな違いはみられない. 図 9 (b)の半径方向平均速度は図 9 (a)の軸方向平均速度にくらべて小さ い. 特に背圧 $1.1 \mathrm{MPa}$ ではこの傾向が顕著である.
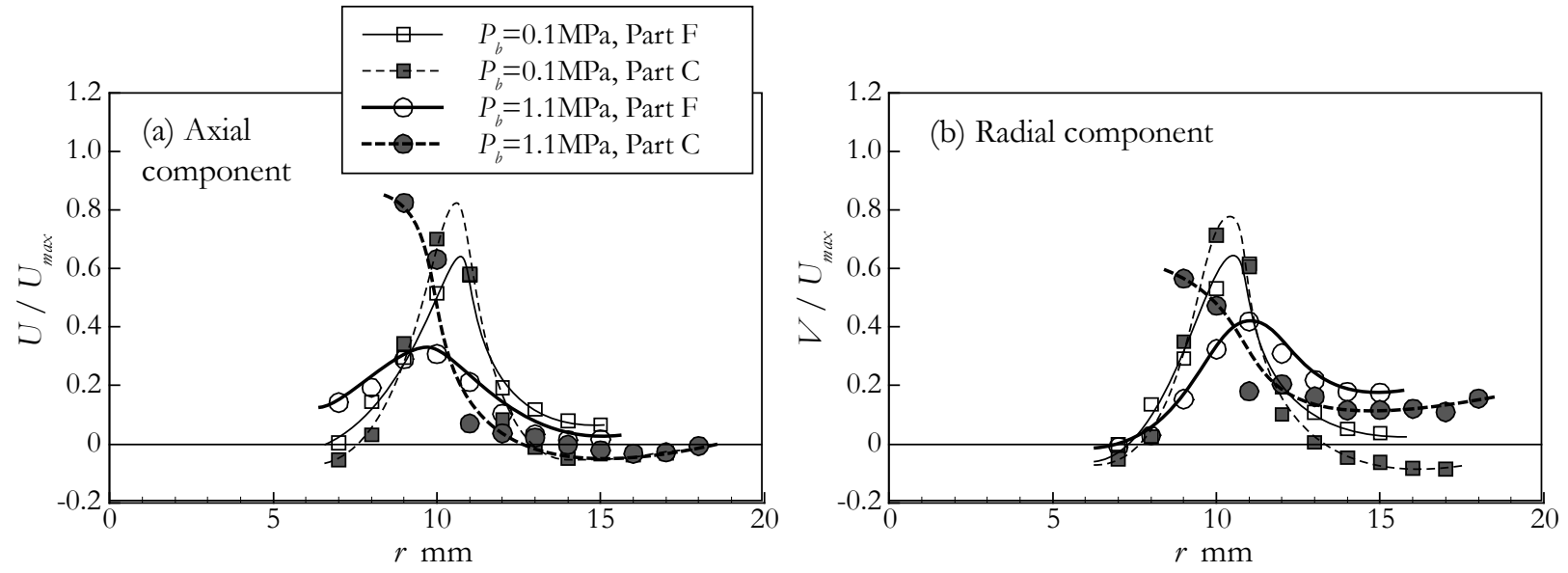

Fig. 12 Radial profile of the mean spray velocity for the outwardly opening type injector at $z=8 \mathrm{~mm}$.
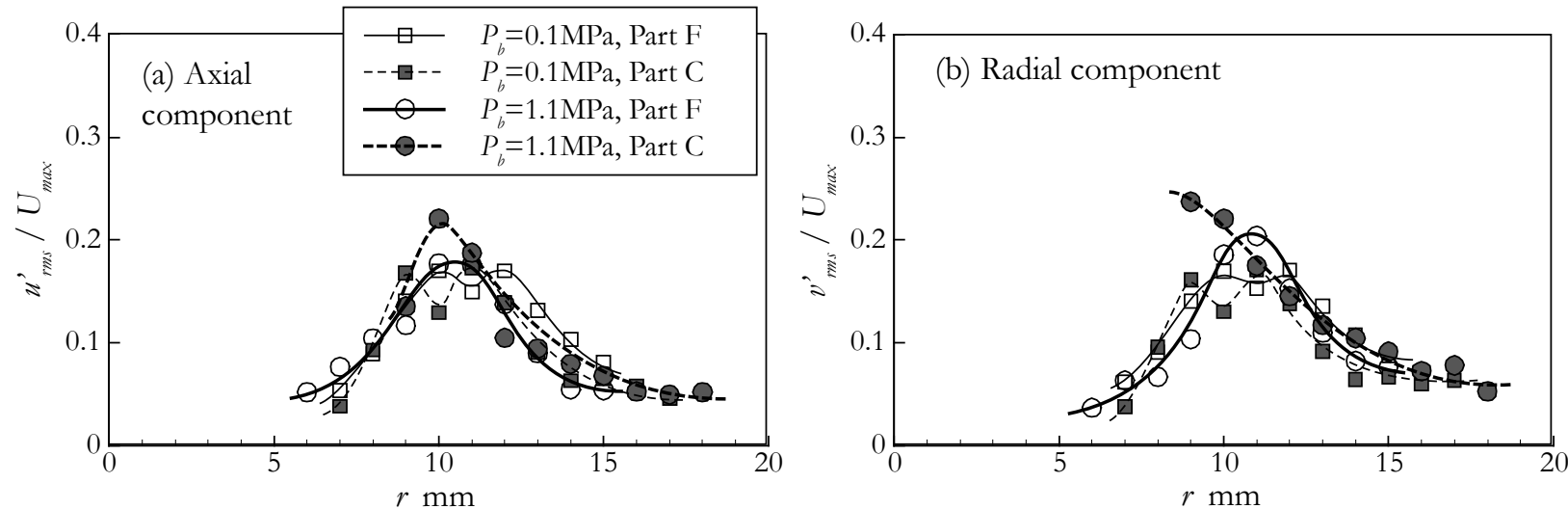

Fig. 13 Radial profile of the velocity fluctuation for the outwardly opening type injector at $z=8 \mathrm{~mm}$.

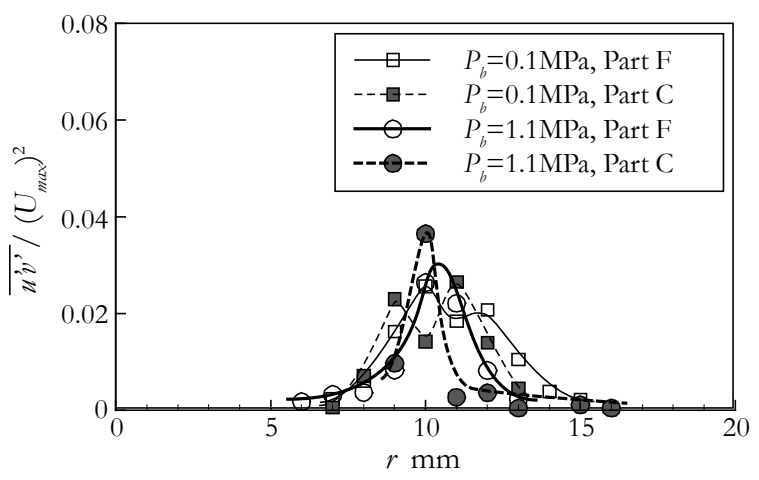

Fig. 14 Correlation of the velocity fluctuation in axial and radial directions for the outwardly opening type injector at $z=8 \mathrm{~mm}$. 


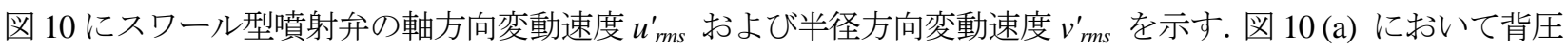
$0.1 \mathrm{MPa}$ では速度勾配の大きい $r=6 \mathrm{~mm}$ 付近で最大值となる. これは速度勾配の大きな領域において $r_{U \operatorname{Umax}}$ 近傍の 高速液滴と噴霧外側部分の低速液滴が混合された結果であると考えられる．なお，F部および C 部で大きな違い はみられない. 背圧 $1.1 \mathrm{MPa} の \mathrm{~F}$ 部では中心部分で最大值をとり, その外側にかけて減少する分布となる. また, $\mathrm{F}$ 部では $r>3 \mathrm{~mm}$ で $\mathrm{C}$ 部にくらべて大きい. 著者らは既報 ${ }^{(5)}$ で，スワール型噴射弁の噴霧の $\mathrm{F}$ 部の軸方向噴霧速 度半径方向分布においてピークの半值となる $r$ 位置から速度勾配がなくなる $r$ 位置の範囲で巻き込みによる渦が 発生していることを示した。このことから，F 部では巻き込み渦が通過している状態であり，巻き込み渦が通過 した後のC部にくらべて変動速度が大きくなると考えられる. 図 10 (b)において背圧 $0.1 \mathrm{MPa}$ の条件では, 図 10 (a) の軸方向変動速度と同程度である. 一方, 背圧 $1.1 \mathrm{MPa}$ の条件では, 半径方向変動速度は軸方向変動速度にくら べて著しく小さくなる．これは図 5 で示したように背圧が大きくなるとスワール噴霧の横方向の発達が非常に小 さくなることに対応している.

図 11 に噴霧の二方向速度相関を示寸. 図 11 の背圧 $0.1 \mathrm{MPa}$ では $r=6 \mathrm{~mm}$ において最大となり，この周辺では

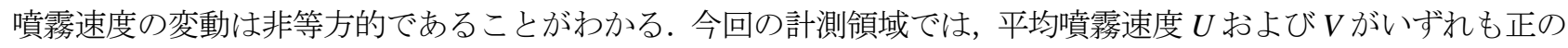
向きであり，これらの合成で得られる絶対速度の方向とその垂直方向に噴霧液滴は拡散し混合するために，二方 向速度相関が正となる．噴霧外縁では噴霧混合が活発でなく 0 に漸近したと考えられる. 背圧 $1.1 \mathrm{MPa}$ の F 部お よびC 部では $\overline{u^{\prime} v^{\prime}}$ はほぼ 0 となる.これは図 10 で示したように背圧 $1.1 \mathrm{MPa}$ では噴霧速度の変動が軸方向に限定 されたためであると考えられる. これらの結果はディーゼル噴霧を含む二相噴流において分散相の主流方向の変 動がそれに垂直方向の変動にくらべて大きくなるという報告(7), (8), (15) と同様の現象が, 背圧が高い条件のスワール 型噴射弁の噴霧で生じたことを示しており, 中心軸方向変動よりも横方向の変動が小さくなることに対応する. すなわち, スワール型噴射弁では背圧を増加させると横方向の発達が著しく抑制され, 噴霧の主流方向(発達方向) は主として噴霧軸方向へと変化する. 以上を総合すると, 噴霧の平均速度および速度変動に加えて $\overline{u^{\prime} v^{\prime}}$ を用いる ことで，噴霧の指向性または混合状態が評価できる可能性があると考えられる.

\section{$3 \cdot 4$ 時間分割法を用いた外開き型噴射弁の噴霧速度評価}

図 12 に外開き型噴射弁の軸方向平均噴霧速度 $U$ および半径方向平均噴霧速度 $V$ を示寸. 図 12 (a)において背圧 $0.1 \mathrm{MPa}$ では $r=10 \mathrm{~mm}$ 付近で最大值をとり, その両側に速度勾配の大きい領域が存在している. また，背圧 0.1 $\mathrm{MPa}$ の C 部の最大值はF 部より $25 \%$ 程度大きい. 背圧 $1.1 \mathrm{MPa}$ の F 部では, $r=10 \mathrm{~mm}$ で最大值となる. 背圧 $1.1 \mathrm{MPa}$ の C 部は噴霧内側部分 $(r<10 \mathrm{~mm})$ で $\mathrm{F}$ 部よりも大きい. スワール型噴射弁とは異なり, 図 12 (b)においていずれ の背圧でも半径方向平均速度は，対応する軸方向平均速度と大きさが同程度であり，分布形状も似ている.

図 13 に外開き型噴射弁の軸方向変動速度 $u_{r m s}^{\prime}$ および半径方向変動速度 $v_{r m s}^{\prime}$ を示す. 図 13 (a)の背圧 $0.1 \mathrm{MPa}$ では $\mathrm{F}$ 部，C 部ともに噴霧中央部分 $(r=10 \mathrm{~mm}$ 付近)で 2 つの極大值をとる. これらの位置は図 12 (a)に示した平 均噴霧速度の速度勾配が大きくなる位置と一致している. 背圧 $1.1 \mathrm{MPa}$ では $\mathrm{F}$ 部，C 部ともに中心部分で一つの 極大值をとる分布となる．これは背圧が高くなることにより噴霧の中心付近のコア部が相対的に小さくなったこ とを示していると考えられる. 図 13 (b)において各条件における半径方向変動速度は, 図 13 (a)に示した対応寸る 軸方向変動速度とほぼ同程度の值で分布形状も同様である.

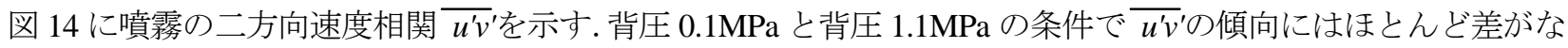
い. これはスワール型噴射弁と異なり，背圧により噴霧の発達方向が変化せず，同様の混合が起きていることを 示しているものと考えられる. 寸なわち，これらの結果は今回使用した外開き型噴射弁による噴霧形成のメカニ ズムが本実験の範囲では背圧にほとんど依存しないことを示していると考えられる．外開き噴射弁の噴霧形成が 背圧に依存しない理由は, スワール噴射弁と比較して, 先立ち噴霧の有無, 噴霧角度の大きさ, 噴霧液滴の数密 度の違いなどが原因として考えられるが, 詳細は今後の研究により明らかにする必要がある. 


\section{4. 結言}

本研究ではスワール型および外開き型噴射弁の噴霧の速度特性を大気圧および $1.1 \mathrm{MPa}$ の背圧条件で計測した. LDA による噴霧速度データに時間分割法を適用し, 噴霧の先端部分 $(\mathrm{F}$ 部)および淮定常部分(C 部)における平均噴 霧速度，変動速度，および二方向速度相関を解析した。得られた結論を以下に示寸。

1. スワール型噴射弁では背圧が増加すると噴霧の半径方向の発達が抑制される. 今回使用した外開き型噴射 弁では背圧が増加しても噴霧の発達方向はほとんど変化しない.

2. スワール型噴射弁の背圧が高い条件では, 他の条件と異なり, 半径方向の平均速度および変動速度が軸方 向にくらべて極端に小さい.

3. スワール型噴射弁の背圧が高い条件では, 噴霧先端部分での変動速度が後続の準定常部分にくらべて大き くなる.

4. 二方向速度相関を評価することにより噴霧形成のメカニズムや噴霧の指向性などが検討可能となる.

実験の遂行にあたり, 群馬大学学生の加藤真亮君, 鶴巻聡君に協力をいただいた. ここに記し感謝の意を表し ます。

\section{文献}

(1) 中山容子, 白石拓也, 野木利治, 大須賀稔, "加圧雾囲気下におけるガソリン間欠噴霧の挙動", 日本機械学会論文集 B 編, Vol. 65, No. 640 (1999), pp. 4113-4116.

（2）石間経章, 助名亮一, 小保方富夫, 河内勝義, 小林一光, "スワール噴射弁における燃料噴射率と噴霧性状の相互評 価法の研究", 日本機械学会論文集 B 編, Vol. 69, No. 678 (2003), pp. 504-511.

(3) Lee, J. K. and Nishida, K., "Simultaneous Flow Field Measurement of D.I. Gasoline Spray and Entrained Ambient Air By LIF - PIV Technique", SAE Paper, No. 2003-01-1115.

(4) Wigley, G., Goodwin, M., Pitcher, G. and Blondel, D., "Imaging and PDA analysis of a GDI spray in the near - nozzle region", Experiments in Fluids, Vol. 36 (2004), pp. 565-574.

（5）小林義幸, 石間経章, 小保方富夫, "スワール噴射弁による間久燃料噴霧の高温高圧場特性", 日本機械学会論文集 B 編, Vol. 74, No. 737 (2008), pp. 221-227.

(6) Wu, K. - J., Santavicca, D. A. and Braco, F. V., "LDV Measurements of Drop Velocity in Diesel - Type Sprays", AIAA Journal, Vol. 22, No. 9 (1984), pp. 1263-1270.

（7）細谷肇，小保方富夫, "高速噴霧流と周囲流の流動特性: 第 1 報, 定常噴霧流の場合", 日本機械学会論文集 B 編, Vol. 58, No. 548 (1992), pp. 1252-1258.

(8) Hardalupas, Y., Taylor, A. M. K. P. and Whitelaw, J. H., "Characteristics of the spray from a diesel injector", International Journal of Multiphase Flow, Vol. 18, No. 2 (1992), pp.159-179.

（9）隆武強，石間経章，小保方富夫, "レーザドップラー法によるディーゼル機関用傘状噴霧流の特性解析: 第 2 報, LDA 法による速度分布の解析", 日本機械学会論文集 B 編, Vol. 62, No. 595 (1996), pp. 1260-1267.

(10) Kim, S. J., Kim, Y. N. and Lee, J. H., "Analysis of the In-Cylinder Flow, Mixture Formation and Combustion Processes in a Spray - Guided GDI Engine", SAE Paper, No. 2008-01-0142.

(11) Befrui, B., Corbinelli, G., Robart, D. and Reckers, W., "LES Simulation of the Internal Flow and Near-Field Spray Structure of an Outward-Opening GDi Injector and Comparison with Imaging Data", SAE Paper, No. 2008-01-0137.

(12) Baumgarten, C., Mixture Formation in Internal Combustion Engines (2006), p. 42, Springer.

(13) Azetsu, A., Dodo, S., Someya, T. and Oikawa, C., "A Study on the Structure of Diesel Spray", COMODIA, (1990), pp. 199 204.

(14) Heywood, J. B., Internal Combustion Engine Fundamentals (1989), pp.331-332, McGraw Hill Higher Education.

(15) Hardalupas, Y., Taylor, A. M. K. P. T. and Whitelaw, J. H., "Velocity and particle-flux characteristics of turbulent particle-laden jets", Proceedings of The Royal Society of London, Series A, Vol. 426, No. 1870 (1989), pp. 31-78. 